\title{
Carbon Disclosure and the Cost of Capital
}

\author{
Die-Lin HE \\ School of Accounting, Zhongnan University of Economics and Law, Wuhan city,China \\ 1270275543@qq.coom
}

Keywords: Carbon Disclosure, Carbon performance, Cost of capital, Voluntary disclosure.

\begin{abstract}
We examine the relation between carbon disclosure and the cost of capital and explore a potential benefit associated with carbon disclosure: a reduction in firm's cost of capital. Employing a sample of U.S. S\&P 500 corporations that present their CDP reporting on the websites of CDP organization, we find that the cost of capital is significantly negative associated with carbon disclosure. However, the negative relation can be mitigated among the firms with superior carbon performance. We also find that the level of carbon disclosure is higher among poor carbon performers than good carbon performers, which can provide some preliminary evidences for legitimacy theory. Our results provide evidence on the rationales behind and the consequences of the recent trend in voluntary carbon disclosure.
\end{abstract}

\section{Introduction}

CDP is an international organization based in the United Kingdom that addresses the climate change concerns of institutional investors. CDP has four strategic principles: to facilitate analysis; to reduce reporting burden; to support investors and companies; and for comparison and decision making(Tran et al. 2011). This independent, not-for-profit organization represents 534 institutional investors with over US\$64 trillion in assets under management, and can be seen as a secondary stakeholder that has facilitated collaborative engagement by institutional investors to increase corporate accountability in relation to climate change(Arenas et al. 2009). It collects climate change data from many of largest corporations globally by asking them to complete its questionnaire. In 2010, CDP sent this questionnaire to more than 4,700 of the world's largest corporations in 2010, requesting information on greenhouse gas (GHG) emissions, on the significant risks and opportunities related to climate change and on the actions companies are taking to manage those risks and opportunities. In U.S., this questionnaire has been sent to S\&P 500 corporations - those considered being representative of the U.S. large-cap equities market. The S\&P 500 saw an increase in response rates, to the highest level ever: up to 70\% (350) in 2010 from 66\% (332) in 2009, 63\% (314) in 2008, and 56\% (280) in 2007. Overall, this activity sends an important message to investors from companies that are managed in the United States-despite legislative uncertainty and nearly three consecutive years of slow economic growth climate change is an important business concern. The rapid increase in CDP reporting naturally raises questions among researchers: What are the rationales behind this type of voluntary disclosure? What benefits do firms gain by spending resources on compiling and publishing these standalone reports?

A number of factors potentially provide answers to these questions, such as the pressure on business to establish and comply with environmental and social norms and standards(Cormier et al. 2005). We examine one factor, namely, a reduction in firms' cost of capital that potentially provides an explanation for the increasing trend in CDP disclosure. Among various potential factors influencing CDP disclosure decisions, we focus on the cost of capital because it plays a critical role in a firm's financing and general operations decisions(Dhaliwal et al. 2011). Also, corporate executives appear to believe that voluntary disclosure can reduce their firm's cost of capital(Graham et al. 2005). Furthermore, there is a longstanding interest among academics in the relation between disclosure and the cost of capital(Diamond and Verrecchia 1991; Botosan 1997; Leuz and Verrecchia 2000; Richardson and Welker 2001; Botosan and Plumlee 2002; Francis et al. 2008; Dhaliwal et al. 2011). 
While these researches have advanced our knowledge about the association between disclosure and the cost of capital, the relation between nonfinancial information such as carbon disclosure and the cost of capital is also interesting. To determine whether carbon disclosure is related to firm's cost of capital, we employ a sample of U.S. S\&P 500 corporations that present their CDP reporting on the websites of CDP organization. Our analyses show that the cost of capital is significantly negative associated with carbon disclosure. However, the negative relation can be mitigated among the firms with superior carbon performance. Thus, the motivation to CDP disclosure by firms with superior carbon performance can be mitigated. In other words, firms with inferior carbon performance may have stronger motivations to publish CDP reports than those firms with superior carbon performance. This study is the first to examine the relations between carbon disclosure and the cost of capital. We contribute to the literature by extending the extant research on voluntary disclosure to another kind of voluntary disclosure, namely, carbon disclosure. Carbon disclosure is related to a firm's long-term development strategies and performance sustainability. Our results provide evidence on the rationales behind and the consequences of the recent trend in voluntary carbon disclosure.

\section{Literature Review and Hypotheses Development}

The relation between financial disclosure and the cost of equity capital has been extensively developed in the past literature (Healy and Palepu 2001; Leuz and Wysocki 2008). The consensus appears to be that a negative relation exists between the quality of financial disclosure and the cost of capital. Greater disclosure increases investors' awareness of a firm's existence and enlarges its investor base, which improves risk-sharing and reduces the cost of capital (Merton 1987).In addition, greater disclosure can lead to reduced information asymmetry among investors or between managers and investors. When the level of disclosure is inadequate and some informational disadvantaged investors become less willing to trade. The resultant illiquidity increases the bid-ask spread and transaction costs(Verrecchia 2001), which leads to a higher required rate of return or cost of capital (Amihud and Mendelson 1986). In a traditional capital markets setting, Lambert et al. (2007) provide theoretical support for a relation between cost of capital and the quality of firms' voluntary disclosures(Lambert et al. 2007). They model the direct and indirect effects of disclosure quality on the cost of capital. The direct effect occurs because higher quality disclosures affect the firm's assessed covariance with other firms' cash flows, which is non-diversifiable. The direct effect on cost of capital can be attributed to a reduction in estimation or information risk, as illustrated in Lambert et al. (2007) and others(Leuz and Verrecchia 2000; Diamond and Verrecchia 1991). The indirect effect occurs because higher quality disclosures affect a firm's real decisions, which likely changes the firm's ratio of the expected future cash flows to the covariance of these cash flows with the sum of all the cash flows in the market. The sign of this indirect affect on the cost of capital is uncertain. They derive conditions under which an increase in information quality leads to an unambiguous decline in the cost of capital. The net effect of increased disclosures on cost of capital is a function of the strength of the relations and whether the indirect effect is positive or negative (as the direct effect is unambiguously negative).

These mechanisms likely apply to both financial and nonfinancial disclosure, as long as the information concerned is value-relevant (Dhaliwal et al. 2011). Indeed, a fair amount of research suggests that CSR information is value-relevant (Al-Tuwaijri et al. 2004; Plumlee et al. 2008; Richardson et al. 1999; Sinkin et al. 2008). Richardson et al. (1999) present a model for how environmental behaviors and the related disclosures impact firm value through net present value assessments of projects, including expected future regulatory costs and market effects(Plumlee et al. 2008). Richardson et al. (1999) argue that there are at least three reasons to expect a negative relation between environmental disclosure and the cost of equity capital (Richardson and Welker 2001). They conclude that there may be a direct influence of environmental disclosure on the cost of equity capital either through investor preference effects, or through reduced information asymmetry or estimation risk. The effects stemming from reduced information asymmetry and/or estimation risk follow directly from the literature on financial disclosure. If information about environmental activities is 
relevant to assessing the firm's prospects, then enhanced disclosure of social activities has the same effect as enhanced disclosure of other financial activities. Investor preference effects arise if investors are willing to accept a lower rate of return on investments by an organization that supports a environmental cause for which some investors have an affinity. In addition, carbon disclosures may be seen as a firm's credible commitment to consider environmental issues in their long-term strategic and production systems (Plumlee et al. 2008). Finally, higher quality environmental disclosures, which have been linked to increased environmental activities, may affect regulators decisions thus impacting costs for firms and for their competitors (Decker and Pope. 2005; Salop and Scheffman 1983). Based on this literature, we predict that firm carbon disclosure will be associated with the cost of capital and test the following hypothesis (stated in alternative form).

H1: The cost of capital is negative associated with the level of carbon.

\section{Sample and Methodology}

\section{Sample Description}

This study uses a cross-sectional research design and firm data for the year 2010 and 2009. We use several criteria to select our sample, a firm must meet the following criteria: (1) In the list of both CDP 2010 S\&P 500 report and CDP 2009 S\&P 500;(2) Have carbon disclosure score and carbon emission data of 2010; (3) Do not experience takeovers, mergers, and acquisitions in 2010 and 2009; (4) The cost of capital can be computed;(5) Have complete financial data reported in COMPUSTAT and CRSP database. The selection processes are conducted step by step. Of the 500 firms included in the 2010 S\&P 500, 350 firms answer the questionnaires from CDP and only 240 firms meet the selection criteria (1)-(3). The cost of capital of 28 firms can not been computed, and 21 firms do not have complete COMPUSTAT and CRSP data. The final sample contains 181 disclosing firms meeting all of the selection criteria.

\section{Empirical Models and Variable Definitions}

Hypothesis 1 predicts that carbon disclosure leads to a lower cost of capital. To test H1, we estimate the following regression model:

$$
\operatorname{COST}_{i, t}=C D_{i, t}+H I C P_{i, t}+C D_{i, t} * H I C P_{i, t}+B E T A_{i, t}+F D_{i, t}+L E V_{i, t}+\operatorname{SIZE}_{i, t}+M B_{i, t}+\sum I N D_{i, t}+\varepsilon_{i, t}
$$

Where COST $\mathrm{T}_{\mathrm{i}, \mathrm{t}}$ is implied cost of equity capital in year t estimated by the PEG formula in (Easton 2004), which is recommended by (Botosan and Plumlee 2005). $C_{\mathrm{i}, \mathrm{t}}$ is a measure of the firm's voluntary carbon disclosure in year t presented by CDP, which is an international collaboration of institutional investors concerned about the business implications of climate change. A negative coefficient on $\mathrm{CD}_{\mathrm{i}, \mathrm{t}}$ would support $\mathrm{H} 1$.

Follwoing Dhaliwal et al. (2011), we include carbon performance $\mathrm{HICP}_{\mathrm{i}, \mathrm{t}}$ and the interact term between $\mathrm{CD}_{\mathrm{i}, \mathrm{t}}$ and $\mathrm{HICP}_{\mathrm{i}, \mathrm{t}}$ in the equation (1). $\mathrm{HICP}_{\mathrm{i}, \mathrm{t}}$ is indicator variable that equals 1 if the firm's carbon performance in year $t$ is higher than the sample median, and 0 otherwise. The other control variables in equation (1) are derived from prior research. The market model BETA $A_{i, t}$, which is estimated using CRSP moth data with a minimum of 30 out of 60 monthly return (Botosan and Plumlee,2005), is included to control for systematic risk. Francis et al. (2008) find earnings quality exerts a influence on the relation between voluntary disclosure and the cost of capital. Hence, we include earnings quality $\left(F D_{i, t}\right)$ in the equation $(1)$. $F D_{i, t}$ is estimated as the absolute value of abnormal accruals estimated based on the modified Jones model. We include leverage (LEV) in equation (1) because (Fama and French 1992) suggest that the cost of capital increases as the degree of leverage increases. We define $\mathrm{LEV}_{\mathrm{i}, \mathrm{t}}$ as the ratio of total debt divided by total assets. Fama and French(1992) also find that expected returns are negatively associated with firm size and positively associated with the book-to-market ratio. Thus, we include firm size $\left(\mathrm{SIZE}_{\mathrm{i}, \mathrm{t}}\right)$ and the market-to-book ratio $\left(\mathrm{MB}_{\mathrm{i}, \mathrm{t}}\right)$ in the equation (1). SIZE $E_{i, t}$ is the natural logarithm of the market value of common equity at the end of year $\mathrm{t}$. $\mathrm{MB}_{\mathrm{i}, \mathrm{t}}$ is market-to-book ratio defined as the market value of equity divided by book value of 
equity at the end of year t. Like Dhaliwal et al. (2011), we also include industry indicators to control for potential industry effects.

\section{Results}

\section{Descriptive Statistics}

Table 1 provides descriptive statistics for the variables in equation (1) for the full sample and separately for firms of different level of carbon disclosure. Table 4 depicts both the parametric and non-parametric, pair-wise correlation coefficients for the variables included in equation (1). The mean of cost of capital among all firms is 9.9 percent. When classified by the level carbon disclosure, the cost of capital is a little lower among top 50 percent firms ( 9.6 percent) than among low 50 percent firms (10.2 percent), and significantly lower $(\mathrm{p}<0.05)$ among top 25 percent firms $(9$ percent) than among low 25 percent firms (10.4 percent). This difference is also reflected in a significantly negative correlation coefficient between $\mathrm{COST}_{\mathrm{t}}$ and $\mathrm{CD}_{\mathrm{t}}$ in Table 4, providing initial support for $\mathrm{H} 1$. The mean of carbon disclosure is 64.16, and carbon disclosure of firms with top level of carbon disclosure is significantly higher $(\mathrm{p}<0.000)$ than firms with low level of carbon disclosure. This difference reflects that different firm's strategies of carbon disclosure are significant different, which provides a rationale for researchers to study the determinants and consequences of firm's carbon disclosure. The mean of carbon performance $\left(\mathrm{CP}_{\mathrm{t}}\right)$ is 0.07 , which indicates that, on average, sample firms generate 0.07 million dollars of sales for every one $\mathrm{CO} 2$-e generated. Consistent with the theory of legitimacy theory, carbon performance is a little better $(\mathrm{p}<0.15)$ among firms with low level of carbon disclosure than firms with top level of carbon disclosure. The correlation coefficient between $\mathrm{CD}_{t}$ and $\mathrm{CP}_{\mathrm{t}}$ is also negative at a relatively moderate level of -0.12 based on the Spearman correlation and -0.10 based on the Pearson correlation.Firms with top level of carbon disclosure are significantly larger than firms with low level of carbon disclosure (Size $\mathrm{t}$ : 10.125 for top 25 percent firms versus 9.435 for low 25 percent firms, $\mathrm{p}<0.01$ ), consistent with (Tang and Luo 2011), which examine the determinants of carbon disclosure in an international setting using Carbon Disclosure Score from CDP.

Table 1 Summary Statistics - Mean Comparison

\begin{tabular}{|c|c|c|c|c|c|c|c|}
\hline \multirow{2}{*}{ Full Sample } & \multicolumn{3}{|c|}{$\mathrm{CD}_{\mathrm{t}}$ (top 50\%=1,low 50\%=0) } & \multicolumn{2}{c|}{$\mathrm{CD}_{\mathrm{t}}$ (top25\%=1,low 25\%=0) } \\
\cline { 3 - 8 } & $\begin{array}{c}\mathrm{CD}_{\mathrm{t}}=1 \\
(\mathrm{n}=88)\end{array}$ & $\begin{array}{c}\mathrm{CD}_{\mathrm{t}}=0 \\
(\mathrm{n}=93)\end{array}$ & $\begin{array}{c}\mathrm{t} \text {-value } \\
\text { (difference) }\end{array}$ & $\begin{array}{c}\mathrm{CD}_{\mathrm{t}}=1 \\
(\mathrm{n}=48)\end{array}$ & $\begin{array}{c}\mathrm{CD}_{\mathrm{t}}=0 \\
(\mathrm{n}=46)\end{array}$ & $\begin{array}{c}\mathrm{t} \text {-value } \\
\text { (difference) }\end{array}$ \\
\hline $\mathrm{COST}_{\mathrm{t}}$ & 0.099 & 0.096 & 0.102 & 1.03 & 0.090 & 0.104 & 2.12 \\
\hline $\mathrm{CD}_{\mathrm{t}}$ & 64.16 & 76.77 & 52.23 & -18.05 & 82.94 & 44.58 & -25.65 \\
\hline $\mathrm{CP}_{\mathrm{t}}$ & .070 & .055 & .084 & 1.21 & .044 & .099 & 1.51 \\
\hline $\mathrm{BETA}_{\mathrm{t}}$ & 1.098 & 1.100 & 1.097 & -0.04 & .967 & 1.078 & 1.02 \\
\hline $\mathrm{FD}_{\mathrm{t}}$ & -.158 & -.168 & -.148 & 0.65 & -.157 & -.138 & 0.46 \\
\hline $\mathrm{LEV}_{\mathrm{t}}$ & .597 & .610 & .586 & -0.92 & .614 & .560 & -1.52 \\
\hline $\mathrm{SIZE}_{\mathrm{t}}$ & 9.755 & 9.887 & 9.631 & -1.49 & 10.125 & 9.435 & -2.84 \\
\hline $\mathrm{MB}_{\mathrm{t}}$ & 3.300 & 3.570 & 3.043 & -1.10 & 3.789 & 3.090 & -0.99 \\
\hline All continuous variables are winsorized at the $1^{\text {st }}$ and $99^{\text {th }}$ percentiles. \\
\hline
\end{tabular}

\section{Regression Analysis}

Hypothesis 1 predicts that the cost of capital is negatively associated with the level of carbon disclosure. Table 2 shows the regression results. In Column I, the coefficient on CD is insignificant (coefficient $=-0.0002, \mathrm{p}>0.20$ ). It appears that carbon disclosure per se is not significantly associated with the cost of capital. In Column II, we examine that investors are likely to have a different perception due to different pressure from legitimacy between poor carbon performers and good carbon performers. The coefficient on CD is significant (coefficient $=-0.001, p<0.05$ ), consistent with 
H1, which posits that carbon disclosure reduces the cost of capital. However, the interaction term between CD and HICP is significantly positive $(p<0.05)$, which indicates the negative relation between carbon disclosure and the cost of capital can be mitigated while the firms have superior carbon performance. One possible explanation for this result is that investors and other stakeholders pay more attention on carbon disclosure among firms with inferior carbon performance than firms with superior carbon performance, because poor carbon performers may face more regulation risks, physical risks and other risks than good carbon performers, which may result in big losses in investments. Since good carbon performers have fewer risks from carbon emission, investors and other stakeholders pay less attention on carbon disclosure presented by those firms. Thus, the negative relation between carbon disclosure and the cost of capital among firms with superior carbon performance may be mitigated. Another possible explanation is consistent with legitimacy theory. Firms with inferior carbon performance may present carbon information better than those firms with superior carbon performance. Thus, the transparency of carbon information is higher among poor carbon performers than good carbon performers. Based on the level of transparency of carbon disclosure, investors and other stakeholders can make appropriate decisions. If the transparency of carbon information is so low to some extent, which often occurs in good carbon performers due to significantly negative relation between carbon disclosure and carbon performance, investors and other stakeholders may not make appropriate decisions based on carbon information. Therefore, for good carbon performers, the significantly negative relation between carbon disclosure and the cost of capital may be mitigated. Further, it can be inferred that poor carbon performers have stronger motivations to publish high quality CDP reports than good carbon performers. In Column III, we obtain identical results when we exclude financial industry. Overall, the evidence is consistent with $\mathrm{H} 1$ that poor carbon performers can achieve a reduction in the cost of capital.

Table 2 OLS Regression Results

\begin{tabular}{|c|c|c|c|}
\hline Variables & Eq. (1) & Eq. (2) & Removing Financials \\
\hline \multirow[t]{2}{*}{$C D_{t}$} & -0.0002 & $-0.001^{* *}$ & $-0.001 * * *$ \\
\hline & $(-1.174)$ & $(-2.409)$ & $(-2.660)$ \\
\hline \multirow[t]{2}{*}{$\mathrm{HICP}_{t}$} & & $-0.047 * *$ & $-0.052 * * *$ \\
\hline & & $(-2.205)$ & $(-2.629)$ \\
\hline \multirow[t]{2}{*}{$C D_{t} * H I C P_{t}$} & & $0.001^{* *}$ & $0.001^{* * *}$ \\
\hline & & $(2.331)$ & $(2.713)$ \\
\hline \multirow[t]{2}{*}{$B E T A_{t}$} & $0.022 * * *$ & $0.020 * * *$ & $0.019 * * *$ \\
\hline & $(3.881)$ & $(3.687)$ & $(3.483)$ \\
\hline \multirow[t]{2}{*}{$F D_{t}$} & -0.020 & -0.019 & -0.015 \\
\hline & $(-1.365)$ & $(-1.203)$ & $(-0.999)$ \\
\hline \multirow[t]{2}{*}{$L E V_{t}$} & 0.012 & 0.012 & 0.011 \\
\hline & $(0.638)$ & $(0.687)$ & $(0.640)$ \\
\hline \multirow[t]{2}{*}{$S I Z E_{t}$} & $-0.005^{* *}$ & $-0.006 * *$ & $-0.006 * *$ \\
\hline & $(-2.308)$ & $(-2.599)$ & $(-2.552)$ \\
\hline \multirow[t]{2}{*}{$M B_{t}$} & -0.001 & -0.001 & -0.001 \\
\hline & $(-1.517)$ & $(-1.586)$ & $(-1.482)$ \\
\hline cons & $0.141 * * *$ & $0.136 * * *$ & $0.135 * * *$ \\
\hline Industry Indicators & Yes & Yes & Yes \\
\hline Adjusted $R^{2}$ & 0.252 & 0.267 & 0.267 \\
\hline$F$ & $5.04 * * *$ & $4.86 * * *$ & $4.87 * * *$ \\
\hline$n$ & 181 & 181 & 171 \\
\hline \multicolumn{4}{|c|}{$\begin{array}{l}*, * *, * * * \text { Indicate that the estimated coefficient is statistically significant at the } 10 \\
\text { percent, } 5 \text { percent and } 1 \text { percent levels, respectively. All continuous variables are } \\
\text { winsorized at the } 1^{\text {st }} \text { and } 99^{\text {th }} \text { percentiles. }\end{array}$} \\
\hline
\end{tabular}




\section{Additional Analysis}

\section{Alternative Cost of Capital Measure}

We investigate the sensitivity of our main results to other ex ante cost of capital metrics: debt ratings (an ex ante cost of debt measure). We use debt ratings because it allows us to sidestep the debate about which is the "best" ex ante cost of equity proxy(Francis et al. 2008), and because Sengupta (1998) concludes that disclosure quality (as measured by AIMR scores) is negatively associated with cost of debt. For the debt rating test, we use S\&P credit ratings as available on Compustat. Debt ratings can range from AAA (highest quality) to $\mathrm{D}$ (default). We employ the numeric transformation rules of S\&P credit ratings in Francis et al. (2008), and lose firms that have no debt ratings. We obtain similar results when we exclude financial industry.

\section{Alternative Carbon Performance Proxy}

In the prior analysis, we use the inverse of total carbon emission per thousand dollar sales turnover (net) to measure firm's carbon performance. Total carbon emission consists of Scope 1 emission, Scope 2 emission, and Scope 3 emission. Under regulations such as the EU-ETS( The EU Emissions Trading System (EU-ETS) is a cornerstone of the European Union's policy to combat climate change and its key tool for reducing industrial greenhouse gas emissions cost-effectively. Being the first and biggest international scheme for the trading of greenhouse gas emission allowances, the EU-ETS covers some 11,000 power stations and industrial plants in 30 countries.), it is specifically (part of) these Scope 1 emissions for which a firm is held accountable, and, not surprisingly, these types of emissions are reported most widely. Since indirect emissions, Scope2 come from sources where the point of release is not within the firm itself, but either upstream or downstream in the supply chain, and Scope 3 emissions are not still well-defined, many firms do not disclose the information of Scope 2 emissions and Scope 3 emissions, the numbers of Scope 2 emissions and Scope 3 emissions may be incomparable to some extent among different firms. Thus, we also use the inverse of Scope 1 emissions per thousand dollar sales turnover (net) to measure firm's carbon performance. We find that the regression results using this kind of carbon performance proxy are consistent with those presented in our main analysis, except that the coefficient of market-to-book ratio (MB) in equation (2) is statistically significant at a moderate level (coefficient $=-0.001, \mathrm{p}<0.1$ ) now, which is consistent with the results by Dhaliwal et al.(2011).

\section{Conclusions and Limitations}

This study investigates the relation between carbon disclosure and the cost of capital. We extend the traditional research on voluntary disclosure from the narrow focus of financial disclosure to nonfinancial disclosure-carbon disclosure. Voluntary carbon disclosure is related to a firm's long-term development strategies and performance sustainability. The study of the relation between carbon disclosure and the cost of capital contribute to understanding not only firm's development strategies and motivation of voluntary disclosure, but also the consequences of these strategies. We find that carbon disclosure is significantly negative associated with the cost of capital. However, the negative relation between carbon disclosure and the cost of capital may be mitigated among good carbon performers.

Like all cross-sectional studies, limitations to interpreting our results apply regarding whether the time period examined is representative and the observed relations among the variables of interest are relatively stable over time. Another limitation is that our sample, drawn from S\&P 500 firms, induces a size bias. However, due to CDP questionnaires only sent to S\&P 500 firms in U.S. until now, we cannot tackle with this issue. Whereas our results may be generalized for large firms, inferring that small firms may behave similarly is overreaching. Although we acknowledge these limitations, we believe that our study opens various venues for future research. For example, the effect of carbon disclosure could be a function of differences in legal environment and institutional setting. Therefore, an international study could help us better understand CSR disclosure. 


\section{References}

[1] Al-Tuwaijri, S. A., T. E. Christensen, and K. E. Hughes. 2004. The relations among environmental disclosure, environmental performance, and economic performance: a simultaneous equations approach. Accounting, Organizations and Society 29 (5-6):447-471.

[2] Botosan, C. A., and M. A. Plumlee. 2005. Assessing Alternative Proxies for the Expected Risk Premium. The Accounting Review 80 (1):21-53.

[3] Core, J. E. 2001. A review of the empirical disclosure literature: discussion. Journal of Accounting and Economics 31 (1-3):441-456.

[4] Dhaliwal, D. S., L. Oliver Zhen, A. Tsang, and Y. Yong George. 2011. Voluntary Nonfinancial Disclosure and the Cost of Equity Capital: The Initiation of Corporate Social Responsibility Reporting. Accounting Review 86 (1):59-100.

[5] Easton, P. D. 2004. PE Ratios, PEG Ratios, and Estimating the Implied Expected Rate of Return on Equity Capital. The Accounting Review 79 (1):73-95.

[6] Fama, E. F., and K. R. French. 1992. The Cross-Section of Expected Stock Returns. The Journal of Finance 47 (2):427-465.

[7] Francis, J., D. Nanda, and P. Olsson. 2008. Voluntary disclosure, earnings quality, and cost of capital. Journal of Accounting Research 46 (1):53-99

[8] Healy, P. M., and K. G. Palepu. 2001. Information asymmetry, corporate disclosure, and the capital markets: A review of the empirical disclosure literature. Journal of Accounting and Economics 31 (1-3):405-440.

[9] Lambert, R., C. Leuz, and R. E. Verrecchia. 2007. Accounting Information, Disclosure, and the Cost of Capital. Journal of Accounting Research 45 (2):385-420.

[10] Leuz, C., and P. Wysocki. 2008. Economic consequences of financial reporting and disclosure regulation: A review and suggestions for future research: University of Chicago.

[11] Patten, D. M. 1992. Intra-industry environmental disclosures in response to the Alaskan oil spill: A note on legitimacy theory. Accounting, Organizations and Society 17 (5):471-475.

[12] Plumlee, M., D. Brown, and S. Marshall. 2008. The impact of voluntary environmental disclosure quality on firm value: University of Utah.

[13] Richardson, A. J., and M. Welker. 2001. Social disclosure, financial disclosure and the cost of equity capital. Accounting, Organizations and Society 26 (7-8):597-616.

[14] Richardson, A. J., M. Welker, and I. R. Hutchinson. 1999. Managing Capital Market Reactions to Corporate Social Resposibility. International Journal of Management Reviews 1 (1):17-43.

[15] Sinkin, C., C. J. Wright, and R. D. Burnett. 2008. Eco-efficiency and firm value. Journal of Accounting and Public Policy 27 (2):167-176.

[16] Tang, Q., and L. Luo. 2011. Transparency of Corporate Carbon Disclosure: International Evidence. Sydney: University of Western Sydney, 1-48.

[17] Tran, J., O. Okafor, and I. M. Herremans. 2011. GAAP for GHG Emissions Accounting:How Consistent are GHG Emissions Reported Among Different Channels? .

[18] Verrecchia, R. E. 2001. Essays on disclosure. Journal of Accounting and Economics 32 (1-3):97-180. 